
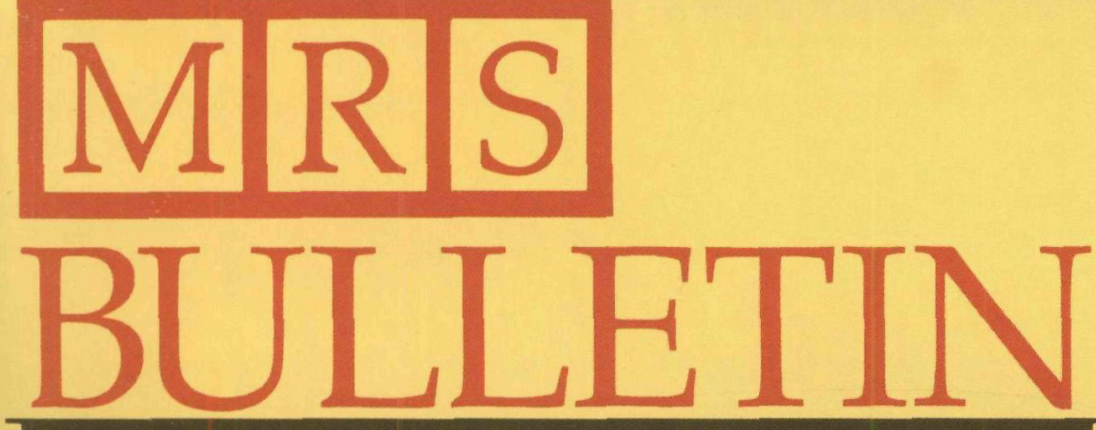

Serving the International Materials Research Community

January 1992, Volume XVII, No. 1

A Publication of the Materials Research Society

maxtient anow

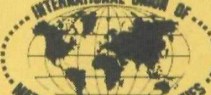

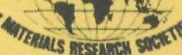

\title{
Art and \\ Technology
}
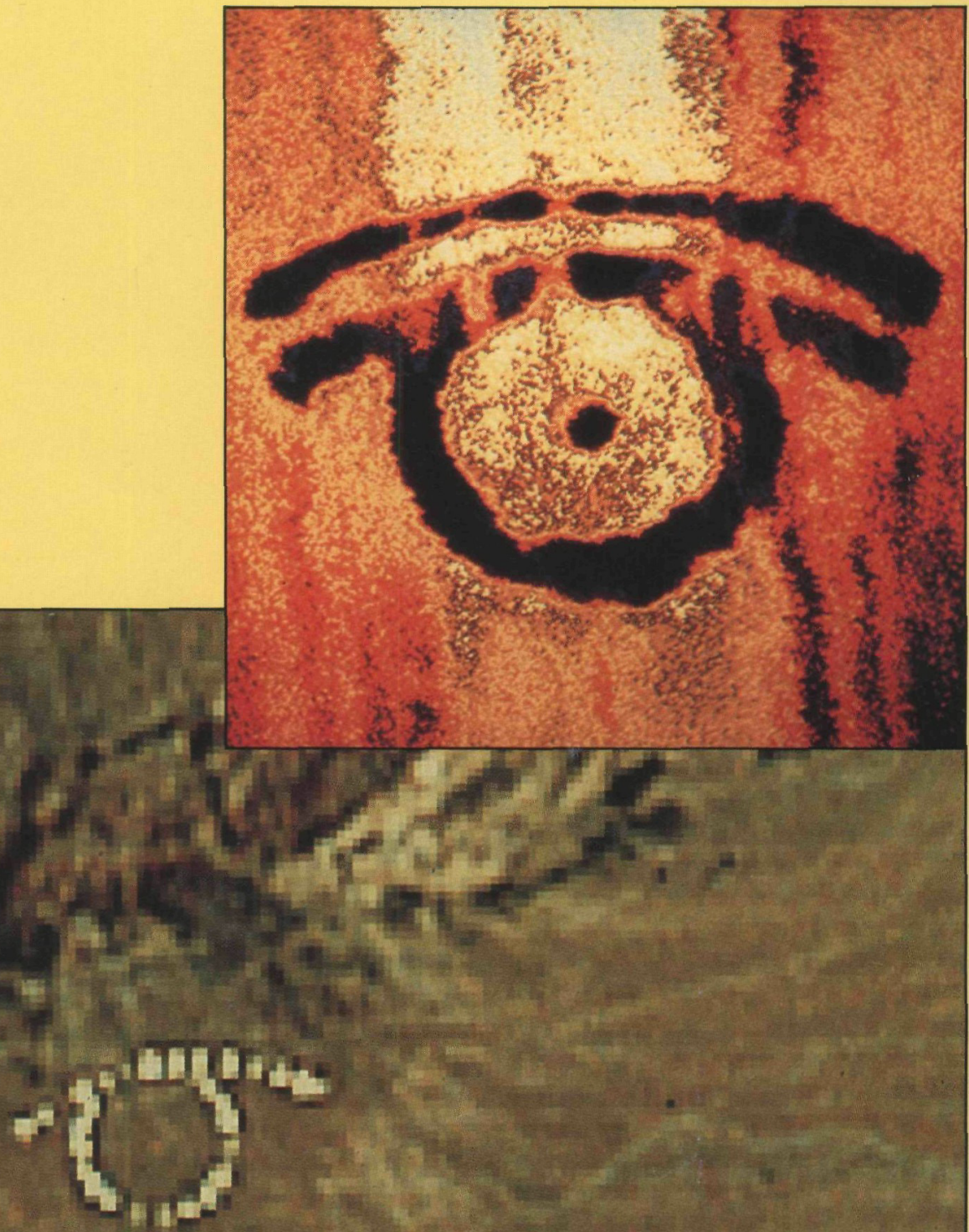



\section{ART AND TECHNOLOGY}

14 Art and Technology

P.B. Vandiver and J.R. Druzik

18 Art-and-Technology: Recent Efforts in Materials and Media
0 . Piene

24 Coulomb's Data on Harpsichord Wire

M. Goodway and W.R. Savage

28 Processes and Performance in Renaissance Painting I.C. Alexander

32 Old and New World Spanish Majolica Technology

J.S. Olin and J.E. Myers

39 Novel Approaches for Assessing the Preservation of Historic Silks: A Case Study of the First Ladies' Gowns

M.A. Becker and N. Tuross

46 An 8,500-Year-Old Sculpted Plaster Head from Jericho (Israel)

W.D. Kingery, P.B. Vandiver, and T. Noy

53 AMS Radiocarbon Dating: Its Current and Future Role in Art Research

D.C. Stulik and D.J. Donahue

\section{SPECIAL FEATURE}

62 Up Close: Materials Science in Spain-Its Dynamic Growth

C. Ortiz and D. Gonzalez

\section{MRS NEWS}

52 Koch, Pennycook, and White Will Chair 1992 MRS Fall Meeting

\section{DEPARTMENTS}

3 Letter from the President

4 Material Matters

6 Research/Researchers

11 Resources

12 From Washington

31 Advertisers in This Issue

38 Section News

61 Historical Note

66 Book Reviews

67 Calendar

70 Classified

72 Posterminaries

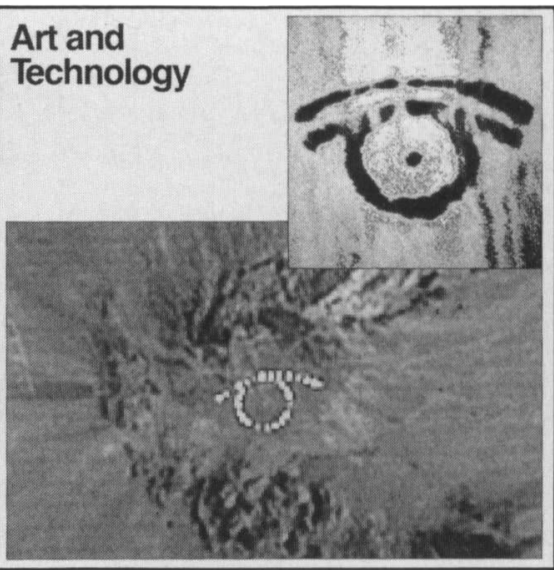

ON THE COVER: Contrasting very small (250 $\mathrm{nm})$ and very large $(2.5 \mathrm{~km})$ drawings of a human eye. The upper image, a collaboration between artist Tom Van Sant and M.S.

Isaacson, M. Muray, and E.J. Kirkland called "Ryan's Eye," is an electron micrograph of an eye etched into the surface of a salt crystal with an electron beam. The etching was done in 1982 at Cornell University's National Research and Resource Facility for Submicron Structures (now the National Nanofabrication Facility). The lower image, a collaboration between Van Sant and many scientists and engineers in the Landsat program, is called "'Reflections from Earth." The satellite-imaged solar reflections of mirrors form the composite shape of an eye in the Mojave Desert. This image is 10 billion times the size of the etched eye, with the size of the human eye $(2.5 \mathrm{~cm})$ in the center of the scale. The measurements and calculations were certified by R.P. Feynman of Caltech. For more information, see "Art-and-Technology: Recent Efforts in Materials and Media" by 0 . Piene on p. 18. 
Materials Research Society • 9800 McKnight Road • Pittsburgh, PA 15237

\section{About the Materials Research Society}

The Materials Research Society (MRS), a nonprofit scientific association founded in 1973, promotes interdisciplinary goal-oriented basic research on materials of technological importance. Membership in the Society includes more than 10,000 scientists, engineers, and research managers from industrial, government, and university research laboratories in the United States and more than 40 countries.

The Society's interdisciplinary approach differs from that of single-discipline professional societies because it promotes information exchange across the many technical fields touching materials development. MRS sponsors two major international annual meetings encompassing approximately 50 topical symposia, and also sponsors numerous single-topic scientific meetings. The Society recognizes professional and technical excellence, conducts short courses, and fosters technical interaction in local geographic regions through Sections and University Chapters.

MRS participates in the international arena of materials research through the International Union of Materials Research Societies (IUMRS). MRS is an affiliate of the American Institute of Physics.

MRS publishes symposium proceedings, MRS Bulletin, Journal of Materials Research, and other publications related to current research activities.

MRS Bulletin (ISSN: 0883-7694) is published 12 times a year by the Materials Research Society, 9800 McKnight Road, Pittsburgh, PA 15237. Application to mail at second class rates has been approved at Pittsburgh, PA and at additional mailing offices. POSTMASTER: Send address changes to MRS Bulletin in care of the Materials Research Society, at the address listed; phone (412) 367-3003; Fax (412) 367-4373

Membership in MRS is $\$ 70$ annually for regular members, \$25 for students and retired members. Dues include an allocation of $\$ 25$ ( $\$ 15$ for students and retirees) to a subscription to MRS Bulletin. Individual member subscriptions are for personal use only. Non-member subscription rates are $\$ 95$ for one calendar year (12 issues) within the U.S.A. and $\$ 140$ elsewhere. Single copies may be purchased for $\$ 15$ each. Send subscription orders to Subscription Department, Materials Research Society, 9800 McKnight Road, Pittsburgh, PA 15237.

MRS Bulletin is included in Current Contents/Physical, Chemical \& Earth Sciences ${ }^{\mathrm{TM}}$ and Research Alert. Back volumes of MRS Bulletin are available in $16 \mathrm{~mm}$ microfilm, $35 \mathrm{~mm}$ microfilm, or $105 \mathrm{~mm}$ microfiche through University Microfilms Inc., 300 North Zeeb Road, Ann Arbor, Michigan 48106 .

\section{MRS BULLETIN}

Publisher

G. A. Oare

Technical Editor

E. L. Fleischer

Assistant Editor

F. M. Wieloch

Copy Editor

D. M. Varner

Art Director

C. Love

Design/Production

W. A. McCalip, J. Probert
Editorial Assistants

J. Dininny, M. M. Costello

Advertising and Circulation M. E. Kaufold

Associate Editor-Europe

I. W. Boyd

University College London

Dept. of Electronic and

Electrical Engineering

Torrington Place

London WCI E7 JE

United Kingdom

$71-387-7050$ ext. 3956 or 7304
Editorial and Advertising Offices

9800 McKnight Road

Pittsburgh, PA 15237

Telephone (412)-367-3036

Fax (412) 367-4373

MRS Office of Public Affairs

Washington DC 20009

Telephone (202) 483-6771

Guest Editors

P. B. Vandiver, J. R. Druzik

Special Contribulors

K. J. Anderson, L. V. Interrante
2000 Florida Ave. NW, Third Floor

CHAIRMAN-EDITORIAL BOARDS

E. N. Kaufmann • Argonne National Laboratory • Argonne, Illinois, USA

\section{NTERNATIONALADVISORY BOARD}

M. Balkansk

University of Pierre and Marie Curie

Paris, France

R. G. Elliman

Australian National University

Canberra, Australia

S. Hsu

Chung Shan Institute of Science

and Technology

Taiwan, China

\section{TECHNICAL EDITORIAL BOARD}

J. C. Bravman

Stanford University

Stanford, California, USA

C. W. Draper

AT\&T Engineering Research Center

Princeton, New Jersey, USA

E. Fogarassy

Centre de Recherches Nucléaires

L. C. lanniello
U. S. Department of Energy
Washington, DC, USA
H-D. Li
Tsinghua University
Beijing, China
P. Rama Rao
Ministry of Science and
Technology
New Delhi, India

\section{F. Y. Fradin}

Argonne National Laboratory

Argonne, Illinois, USA

B. M. Leon

Universidade de Santiago

Vigo, Spain

G. L. Lied

Purdue University

\author{
R. Roy \\ Pennsylvania State University \\ University Park, Pennsylvania, USA \\ T. Sugano \\ University of Tokyo \\ Tokyo, Japan \\ D. L. Weaire \\ University of Dublin \\ Dublin, Ireland
}

\begin{abstract}
Strasbourg, France
West Lafayette, Indiana, USA
\end{abstract}

\section{MRS BULLETIN PUBLICATIONS SUBCOMMITTEE}

\section{A. Barkatt}

Catholic University of America

Washington, DC

A. J. Hurd

Sandia National Laboratories

Albuquerque, New Mexico

M. R. Libera

Stevens Institute of Technology

Hoboken, New Jersey

\section{G. J. McCarthy}

North Dakota State University

Fargo, North Dakota

J. M. Phillips

AT\&T Bell Laboratories

Murray Hill, New Jersey

S. M. Prokes

Naval Research Laboratory

Washington, DC

\section{S. Namba \\ Osaka University \\ Osaka, Japan}

A. D. Romig Jr.

Sandia National Laboratories

Albuquerque, New Mexico, USA

J. Soares

Universidade de Lisboa

Lisboa, Portugal

K. C. Taylor

General Motors Research Laboratories Warren, Michigan, USA

\section{W. H. Sutton \\ United Technologies}

Research Center

East Hartford, Connecticut

C. W. White

Oak Ridge National Laboratory

Oak Ridge, Tennessee

\section{MRS EXECUTIVE COMMITTEE}

\section{President}

G. S. Cargill III

IBM T. J. Watson Research Center

First Vice President and President-Elect

S. T. Picraux

Sandia National Laboratories

\section{Secretary}

Oak Ridge National Laboratory

Treasurer

C. B. Duke

Xerox Research Laboratories
Immediate Past President

J. B. Roberto

Oak Ridge National Laboratory

Executive Director

Materials Research Society

John B. Ballance

\section{Second Vice President}

J. C. Bravman

Stanford University

\section{INTERNATIONAL UNION OF MATERIALS RESEARCH SOCIETIES}

President

R. P. H. Chang

Northwestern University, USA

Tel. (708) 491-3598; Fax (708) 491-4181
Vice President

Paul Siffert

Centre de Recherches Nucléaires, France

Tel. (88) 2865 43; Fax (88) 280990

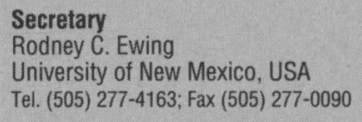

Treasurer

Shigeyuki Sömiya

Nishi Tokyo University, Japan

Tel. (81) 3417 2866; Fax (81) 34156619
Materials Research Society (MRS) James B. Roberto

Chinese Materials Research Society (C-MRS) Hengde Li

European Materials Research Society (E-MRS) B. Stritzker
Materials Research Society of India (MRS-I) C. N. R. Rao

Materials Research Society of Japan (MRS-J) Shigeyuki Sōmiya

Materials Research Society of Korea (MRS-Korea)
Min Che Chon
Materials Research Society of Taiwan (MRS-T)
Ping-Tien Wu
Mexican Materials Research Society (Mexican MRS)
M. J. Yacaman

